still in existence. An interesting introduction closes with an account of the laws applying to local birds; and the volume is embellished with a map of the district, four drawings by Mr. G. E. Lodge, and reproductions of some most beautiful photographs of birds by Mr. Smith Whiting, one of which we are enabled to reproduce.

O. V. Aplin.

\section{THE ADULTERATION OF BUTTER.}

$\mathrm{D}$ RING the last few years much unscrupulous ingenuity has been applied to the sophistication of butter. Both on the Continent and in this country the adulteration of this, the best of edible fats, has developed into quite an industry, having its own factories and its own chemists, and conducting its operations on a scale which, for a furtive, dishonest business, is really of remarkable magnitude. Considerable profits are alleged to be made, and it is therefore not surprising that the traffic has flourished in spite of all attempts at suppression. Perhaps it may be of interest to those readers of Nature who are not chemists to have placed before them, with as little technicality as may be, a sketch of the modern methods of butter-adulteration, and of the means adopted or suggested to checkmate this form of fraud. The importance of the matter both to the consumer and the agriculturist may be pleaded as a justification for discussing the question at some little length.

Butter, though consisting essentially of the fat of milk, is always associated during manufacture with more or less water, the quantity of which ranges generally from 7 to ${ }_{5} 5$ per cent. One of the simplest forms of adulteration consists in working an excessive proportion of water into the butter. To check this is comparatively easy; a maximum limit of 16 per cent. has been fixed by the Board of Agriculture, and persons dealing in butter containing more water than this are liable to prosecution.

There exists, however, an insidious variant of this water-logging in the production of what is called " milk-blended" butter. In preparing this, skim milk, costing about a penny per gallon, is largely used. It may either furnish curd to be incorporated with the butter, or, after a little "ripening" with micro-organisms to improve the flavour, it may be used for direct admixture. By working up butter with such milk a product may be obtained containing 25 to 30 per cent. of water, as well as a substantial quantity of curd. The proportion of butter-fat in such a mixture will often be less than $6_{5}$ per cent., whereas ordinary butter contains from 80 to go per cent. Yet the sale of the article is not, legally, a fraudulent transaction, provided the substance is sold as "milk-blended " butter, and not simply as "butter." At first sight this may seem reasonable enough; the purchaser is told what he is buying, and for the rest-well, caveat emptor. But, after all, some regard should be had to attendant circumstances. It is the poor who chiefly consume the manipulated butter, and neither they, nor, indeed, any ordinary purchaser, would realise that the fat-value of the blended article is only about three-fourths of that of genuine butter. Of course, if the price is correspondingly lower there is no fraud. But the contention of those who oppose the sale is that there is always a substantial margin of unfair profit; " milk-blending," in fact, is held to be essentially a device for supplying an excessive proportion of water, relative to the amount of fat, without incurring the penalties provided for infringemen of the Sale of Butter Regulations.

Be this as it may, a measure to prohibit the use of the word "butter" for such mixtures, on the ground that it is a misleading description, was brought for- ward two or three sessions ago, only to be sacrificed to the exigencies of politics. It remains to be seen whether a better fate is in store for it under the new Administration.

Perhaps, however, the most frequent, and certainly the most troublesome, sophistication of butter consists in the admixture with it of fat other than that of milk. There are two chief adulterants of this class now in use. One is a soft fat obtained from beef-suet by removal of the harder "stearin" portions; this fat may sometimes be mixed with or replaced by lard, and is generally churned up with water (or with milk) to facilitate the subsequent "blending." The other adulterant is a refined cocoa-nut "oil " or fat, purified so as to be practically tasteless. These substances, supplied at about half the price of butter, are variously known as "mixing article," "enricher cream," " neutral fat," or " neutral blending," and are carefully prepared to simulate butter in consistency. A still more subtle adulterant is formed by a judicious mixture of the two, which yields analytical figures identical in some respects with those of genuine butter. Let us examine this a little more closely.

Chemically, butter-fat consists of a mixture of glycerides - that is to say, compounds of fatty acids with glycerin. For instance, one such glyceride may, with sufficient accuracy for our present purpose, be represented as the following combination:-

$$
\text { Glycerin } \left.\begin{array}{l}
\text { Oleic acid } \\
\text { Palmitic acid } \\
\text { Butyric acid }
\end{array}\right\} \text { minus water. }
$$

When these acids are freed from their chemical union with the glycerin, the butyric acid is found to be sharply distinguished from the other two by the fact that it is soluble in water and volatile on distillation with steam. Now the chief difference between butter-fat and other fats lies in the comparatively high proportion of butyric acid (and similar volatile acids) which the butter-fat contains. The following summary represents the composition of a specimen of the prepared beef-fat and of two samples of butter-fat :- -

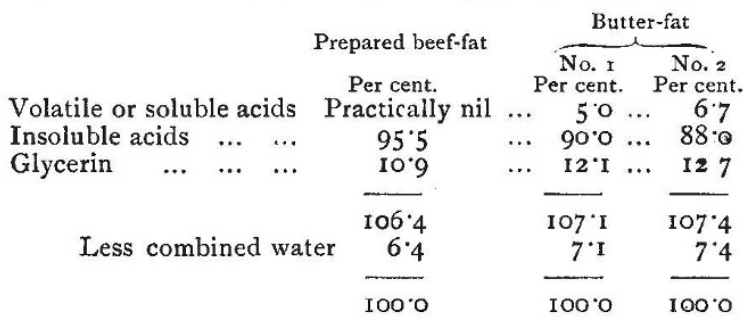

Like other natural products, the fat of milk varies in the proportions of its components, and the two samples here quoted show the range of variation met with in ordinary butter. Analytically, No. I is butter of low quality; No. 2, on the other hand, is above the average. The difference consists, as will be seen, in No. I containing less volatile acids, less glycerin, and more insoluble acids than No. 2. These are precisely the directions in which beef-fat differs from butter-fat. Broadly, one may say that, analytically, the first specimen of butter has more of a beef-fat character than the second.

This is the point which the adulterator seizes upon. "If," he argues, "I start with butter No. 2, I can add to it quite a considerable quantity of my prepared beef-fat before the mixture shows a smaller percentage of volatile axids than butter No. I contains; and since No. I is perfectly genuine butter, it is difficult to see how any analyst will be able to swear that my mixture is not also genuine butter." Indeed, the analyst often finds it no easy matter to expose the

NO. I 898 , vOL. 73 ] 
fraud. If butter had always the same composition the matter would be simple enough. It is the natural variation, small though it be, which has hitherto enabled the sophisticator to pocket his ill-gotten fortune.

This variation arises from a number of causes, of which some at least have been fairly well elucidated. In the main it is due to differences in the feeding and treatment of the cows. For instance, Dr. J. J. L. van Rijn showed some years ago in Holland that with the approach of winter, when grass was becoming poorer and less plentiful, and cows, kept late in pasture, were much exposed to cold, the proportion of volatile acids in the butter became abnormally low; but that as soon as the animals were stabled, and therefore better fed and protected from inclement weather, the volatile acids began to increase. To treat the cows more generously in the matters of warmth and provender was thus the remedy for the abnormality indicated. Nevertheless, there still remain some minor causes of variation, such, for instance, as the different physiological conditions of the cows in varying stages of lactation. The effects of these, however, are largely neutralised when we deal with butter made from the mixed milk of many cows; though they have to be taken into account where nothing is known about the history of a particular specimen of butter.

What, then, it may be asked, are the means by which any check at all can be placed upon the sophistication? Having regard to the variation in admittedly genuine samples, is not analysis useless except in very gross cases of fraud? By no means. Let us see what it can do, and how it may be supplemented.

In his search for adulterants the analyst may determine the following constants of the butterfat he is examining:--(I) Its specific gravity: in butter this is higher than in beef-fat, but lower than in cocoa-nut oil; (2) its refractive index: this again is intermediate in value between those of the two adulterants mentioned; (3) its "saponification " value, which gives a measure of the total quantity of fatty acids and also of the glycerin; and (4) most important of all, the proportion of volatile acids. So far as concerns butter, these physical and chemical data are all correlated with the fact that glycerides of the volatile acids form a relatively large proportion of the genuine fat. They are therefore correlated with one another, and, within limits, are interdependent. The more volatile acid there is, the greater is the specific gravity and the higher the saponification value, whilst the refraction alters inversely. There is thus a kind of parallelism preserved among the constants of genuine butter, notwithstanding the variations in their absolute values. For instance, given genuine butter-fat such as that already referred to as "No. 2," with 6.7 per cent. of volatile acids, one can predict with confidence that its specific gravity will be pretty close to $0.9130\left(37^{\circ} .8 \mathrm{C}\right.$. $)$, and its saponification value not much different from 232. On the other hand, if the butter-fat contains, like No. I, only 5 per cent. of volatile acids, we can say with equal confidence that its specific gravity will be about 0.9105 , and its saponification value approximately 222 .

Suppose, now, an adulterator mixes cocoa-nut oil with the first of these butters until he has reduced the volatile acids from 6.7 per cent. to 5 per cent., the quantity in the second butter. Such an admixture would easily be detected, notwithstanding the fact that the volatile acids correspond in quantity with those of genuine butter. For one thing, these acids can be further examined and made to yield evidence of the admixture; and for another, the addition of the cocoa-nut oil has destroyed the parallelism referred to; the figures are now quite inconsistent with one another, and the sophistication is readily demonstrable. Speaking generally, with a sufficiently extended analysis there is no particular difficulty in detecting relatively small quantities of cocoa-nut oil in butter. But a mere determination of the proportion of volatile acids will not suffice-which explains, perhaps, why this special form of fraud has enjoyed a rather longer life than it might otherwise have had.

The addition of beef-fat or lard is somewhat more difficult to prove. Reliance has chiefly, though not entirely, been placed upon the consequent diminution of the volatile acids. Unfortunately, the natural variation of these in genuine butter is rather considerable, as has been pointed out. Yet even so, it does not follow that the lowest known limit for volatile acids must be taken as the criterion in forming a judgment. There are often collateral circumstances which narrow the range of admissible variation. For instance, a large consignment of " creamery" butter must necessarily, under ordinary commercial conditions, be a product of the mixed milk of many cows, and hence the proportion of volatile acids must tend towards the average value. The minimum quantity, which in exceptional circumstances milk-fat from a single cow might admittedly show, is here lost in the general mean. No weight need be given to it in judging the genuineness of the butter. Similarly, samples purporting to be butter produced in the summer or winter months cannot claim to be judged by the low minimum sometimes found in autumn butter. Again, it may be known, from systematic analyses of genuine butter produced in a certain region, and sampled in circumstances which guarantee the representative character of the samples, that the butter of this region in a specified month did not, as a fact, fall below a particular value in the matter of volatile acids. By having regard to these and similar considerations, as well as to the actual analytical figures, it has been possible in many cases where butter adulterated with beef-fat or lard had been imported into this country from the Continent, not only to prove the fact of the adulteration, but to form a fairly close estimate of its amount.

Some check has thus been placed upon the fraud in question. Yet, although the means at disposal will serve to discover the more considerable amounts of adulteration, there is still a residuum of cases which are either doubtful or in which the legal proof is difficult by reason of the clever way in which advantage has been taken of the natural variation in the constants of butter. To deal with these cases other means are required in supplement of the chemist's work. In Denmark, for instance, there is official supervision of the butter industry; and in Holland the Government has organised an admirable system of State " control," whereby the official imprimatur is accorded to butter produced in factories under the Government inspection. Joining the "control," however, is at present a voluntary matter, and for factories not under it, and which may be suspected of malpractices, a compulsory and more rigid system of inspection has been proposed. In this country a considerable amount of falsification has been going on. Enterprising and unscrupulous individuals import or manufacture the adulterants mentioned above, and offer, in consideration of a substantial fee, to initiate the proprietors of butter-blending factories into the whole art and mystery of butter-" faking." As regards the suppression of this, the Customs authorities in the first instance endeavour to secure that all importations of adulterants coming within the legal definition of margarine shall be marked accordingly,

No. I 898 , VuL 7.37 
in order that their destination may be the better traced. Further, the traffic in the finished mixture nas been somewhat checked by a number of prosecutions, undertaken by Government in the case of imported products, and by a few local authorities in cases where the "blended" butter was sold in this country. But to kill the snake instead of merely scotching it additional weapons are required. Useful measures for this purpose would be: (I) To adopt a recommendation made by a departmental committee some years ago, that a minimal limit for volatile acids should be fixed, below which a presumption should be raised that the butter is not genuine; this would strengthen the hands of the public analyst, and though it would not altogether stop the adulteration, it would restrict its amount and diminish the profits accruing therefrom. (2) To enact that no substance shall be sold as butter if it contains less than 8o per cent. of butter fat; this would prevent the " loading" of butter with curd or "solidified milk." (3) To organise a system of strict inspection of butter factories. (4) To give the Commissioners of Customs greater powers for regulating the admission into this country of adulterated butter and of substances which may be used in the adulteration of butter. (5) Most effective of all would be for the Government of each butter-exporting country to adopt some system modelled on the Netherlands " control " plan of combined inspection and analysis, and to furnish an official voucher of purity, without which the butter would either not be admitted here at all, or only under special conditions of marking. For this, however, we shall have to wait.

C. Simmonds.

A REMARKABLE DISCOVERY IN EGYPT.

\section{$\mathrm{O}^{\mathrm{N}}$} February 7 a most important discovery was made by Prof. Naville at Thebes. The excavation of the eleventh dynasty temple at Deir el-Bahari, discovered by Prof. Naville and Mr. H. R. Hall, of the British Museum, in 1903 , has since been carried on for the Egypt Exploration Fund by these gentlemen, assisted by Mr. E. R. Ayrton. Mr. Ayrton being unable to continue working for the Fund this year, his place was taken by another of the Fund's excavators, Mr. C. T. Currelly, who joined the expedition for the first time this year. During this season work was first carried on by Messrs. Hall and Currelly in the southern court of the temple. Here were discovered some interesting priests' houses (?) of brick, dating from the time of the twelfth to eighteenth dynasties, and the south temenos-wall of the temple. This wall was found to be of the same type as the south wall of the great temple of Queen Hatshepsu, which was thus shown to be in reality the north temenos-wall of the eleventh dynasty temple. Later on Mr. Hall began the excavation of the back part of the temple to see how it ended. He discovered, Prof. Naville says, "the enclosure wall and found that the enclosure was interrupted by a court or wide avenue, lined on both sides by a single row of columns, and directed towards the mountain. The rock had been cut open to make way for the avenue.",

Later on, when Prof. Naville reached Thebes and Mr. Hall left for England, work was directed to the exploration of the remains of an eighteenth dynasty building, also in the back part of the temple, which had been discovered by Messrs. Hall and Ayrton in 1904. At the end of this building was made Prof. Naville's splendid discovery, described by him in the Times recently. It consists of a cell or chapel excavated in the rock, lined with coloured relief sculptures depicting King Thothmes III. making offerings to the god Amen, and in the midst of it was found intact the original cult-image, a great painted and gilded stone cow, of life size. The cow was the emblem of Hathor, goddess of the western deserthills, who was specially venerated at Deir el-Bahari. The image was dedicated by King Amenhetep II., the son and successor of Thothmes III. The chapel belongs really, not to the eleventh dynasty temple, although placed at the end of it, but to the great temple of Deir el-Bahari, with which it is contemporary. The great interest of the figure of the cow, besides its importance as a work of art, lies in the fact that this is the first time that an Egyptian cultimage has been found intact in its shrine. The whole chapel and image will be re-erected in the Museum of Cairo. Illustrations of the find were published in the Graphic and Daily Graphic of March 2.

This discovery is the latest proof of the remarkable nature of Prof. Naville's work for the Egypt Exploration Fund at Deir el-Bahari, which is one of the most interesting sites for archæological work in Egypt, and one of the most productive of interesting small antiquities, chiefly votive offerings to Hathor of the time of the eighteenth dynasty. These often are in the shape of little cows of blue glazed failence, models of the great cult-images in the various caveshrines of Hathor, of which the newly discovered chapel is one, the chief being the well known Hathor-shrine, with the red painted reliefs, on the platform of the great temple, found by Mariette many years ago.

The work of the Egypt Exploration Fund, which is now being carried on by Prof. Naville and his assistants alone, needs considerably more monetary support than is at present being extended to it. It is to be hoped that this discovery will act as an incentive to those who are really scientifically interested in the progress of archæological knowledge, no matter by what person that progress is effected, to give their help to the Egypt Exploration Fund, which discovered Naukratis and the store-city of Pithom, identified the route of the Exodus, excavated Tanis, Bubastis, and Herakleopolis, scientifically explored the tombs of the most ancient kings at Abydos, and is now bringing successfully to an end its most imposing work, the excavation of the two temples of Deir elBahari at Thebes.

\section{NOTES}

THE Bakerian lecture of the Royal Society will be delivered by Prof. John Milne, F.R.S., on Thursday next, March 22, on "Recent Advances in Seismology."

Prof. O. Hertwig, professor of comparative anatomy, University of Berlin, and Prof. H. O. Osborn, professor of zoology, Columbia University, New York, have been elected foreign members of the Linnean Society.

THE annual general meeting of the Chemical Society will be held on Friday, March 30, when the president will deliver his address, entitled " The Living Organism as a Chemical Agency: a Review of some of the Problems of Photosynthesis by Growing Plants.",

AN unprecedented mining disaster occurred on March Io at the Courrières colliery in the department of the Pas de Calais. An explosion of fire-damp resulted in the loss of more than I Ioo lives. The causes of the explosion have not yet been fully established. The colliery employed 6998 persons, and possesses forty-four seams of coal; the annual output is about $2,000,000$ tons. In 1890 attention was directed to this colliery by Sir C. Le Neve Foster on account of the remarkably low death-rate from falls of ground, and it was reported upon by a deputation of H.M. Inspectors of Mines. The average death-rate from NO, I 898 , vOL. 73$]$ 